\title{
PENGARUH BELANJA MODAL TERHADAP PERTUMBUHAN KINERJA KEUANGAN DENGAN PENDAPATAN ASLI DAERAH SEBAGAI VARIABEL INTERVENING (STUDI KASUS PADA PEMERINTAH KABUPATEN/KOTA DI PROVINSI JAWA TIMUR)
}

\author{
Akhmad Imam Amrozi \\ Fakultas Ekonomi, Universitas Islam Lamongan
}

\begin{abstract}
ABSTRAK
Penelitian ini bermaksud untuk menganalisis pengaruh Belanja Modal terhadap pertumbuhan kinerja keuangan dengan Pendapatan Asli Daerah sebagai variabel intervening. Sehubungan dengan masalah tersebut diajukan hipotesis sebagai berikut: Belanja Modal berpengaruh terhadap Pendapatan Asli Daerah, Pendapatan Asli Daerah berpengaruh terhadap pertumbuhan kinerja keuangan, dan Belanja Modal berpengaruh terhadap pertumbuhan kinerja keuangan melalui Pendapatan Asli Daerah sebagai variabel intervening. Sejalan dengan masalah dan hipotesis tersebut maka populasi dari penelitian ini adalah Laporan Realisasi Anggaran Pendapatan Belanja Daerah Kabupaten/Kota di Provinsi Jawa Timur tahun 2013 dan sebagai sampel yaitu Belanja Modal, Pendapatan Asli Daerah, dan variabel yang menjadi parameter untuk pengukuran kinerja keuangan Kabupaten/Kota di Provinsi Jawa Timur. Data yang digunakan yaitu data sekunder, untuk mendapatkan data yang lebih akurat maka metode yang digunakan yaitu dokumentasi. Metode analisis yang digunakan yaitu statistik deskriptif, uji asumsi klasik, regresi linier berganda, dan analisis jalur. Belanja Modal berpengaruh positif dan signifikan terhadap Pendapatan Asli Daerah, Pendapatan Asli Daerah berpengaruh positif dan signifikan terhadap pertumbuhan kinerja keuangan (rasio kemandirian), Pendapatan Asli Daerah berpengaruh positif dan signifikan terhadap pertumbuhan kinerja keuangan (kemampuan mobilisasi daerah), Pendapatan Asli Daerah tidak berpengaruh secara negatif dan tidak signifikan terhadap pertumbuhan kinerja keuangan (efisiensi penggeluaran anggaran), Pendapatan Asli Daerah berpengaruh secara negatif dan tidak signifikan terhadap pertumbuhan kinerja keuangan (sisa pengeluaran anggaran), Belanja Modal secara signifikan berpengaruh positif secara tidak langsung terhadap pertumbuhan kinerja keuangan dengan Pendapatan Asli Daerah sebagai variabel intervening.
\end{abstract}

Kata kunci : Belanja Modal, Pendapatan Asli Daerah, Kinerja Keuangan

\section{PENDAHULUAN}

Otonomi daerah merupakan

kebijakan yang diambil oleh pemerintah

pusat agar pemerintah daerah semakin mandiri, mengurangi ketergantungan terhadap pemerintah pusat, baik dalam hal pembiayaan pembangunan maupun dalam hal pengelolaan keuangan daerah. 
Pengelolaan keuangan daerah yang baik akan berpengaruh terhadap kemajuan suatu daerah, hal ini tidak hanya membutuhkan sumber daya manusia yang yang handal tetapi juga harus didukung oleh kemampuan keuangan daerah yang memadai. Salah satunya diukur dari besarnya penerimaan daerah khususnya Pendapatan Asli Daerah. PAD menjadi tulang punggung yang digunakan untuk membiayai belanja daerah, salah satu adalah belanja modal.

Pendapatan Asli Daerah dalam penelitian ini digunakan sebagai variabel intervening. Peningkatan PAD sebagai salah satu sumber pembiayaan daerah yang diharapkan dapat meningkatkan kualitas kinerja pemerintahan. Namun kenyataannya banyak daerah yang belum mampu untuk menyusun laporan keuangan yang sesuai dengan pedoman dan aturan yang disusun oleh pemerintah pusat. Jalan keluar dari permasalahan tersebut adalah pemerintah daerah mampu untuk mengidentifikasi perkembangan kinerjanya dari tahun ke tahun. Salah satu alat untuk menganalisis kinerja pemerintah daerah dengan melakukan analisa rasio keuangan terhadap Anggaran Pendapatan dan Belanja Daerah (APBD). Sehingga peneliti tertarik untuk meneliti pengaruh belanja modal terhadap pertumbuhan kinerja keuangan dengan PAD sebagai variabel intervening pada pemerintah Kabupaten/Kota di Provinsi Jawa Timur.

Pertanyaan dalam penelitian ini adalah (1) Apakah belanja modal memiliki pengaruh terhadap Pendapatan Asli Daerah? (2) Apakah Pendapatan Asli Daerah memiliki pengaruh terhadap pertumbuhan kinerja keuangan? Apakah belanja modal memiliki pengaruh terhadap pertumbuhan kinerja keuangan dengan Pendapatan Asli Daerah sebagai variabel intervening? Adapun tujuan dari penelitian ini adalah untuk mengetahui pengaruh belanja modal terhadap pertumbuhan kinerja keuangan dengan Pendapatan Asli Daerah sebagai variabel intervening.

\section{TINJAUAN PUSTAKA}

\subsection{Pendapatan Asli Daerah}

Pendapatan Asli Daerah merupakan semua penerimaan daerah yang berasal dari sumber ekonomi asli daerah (Wenny, 2012: 41). PAD dipisahkan menjadi 4 jenis pendapatan, yaitu: (a) Pajak daerah (b) Retribusi daerah (c) Hasil pengelolahan kekayaan milik daerah yang dipisahkan (d) Lain-lain PAD yang sah. 


\subsection{Belanja Modal}

Berdasarkan

Undang-Undang

Nomor 71 Tahun 2010 tentang Standar Akuntansi Pemerintahan, pengertian Anggaran Pendapatan dan Belanja Daerah (APBD) adalah satu rencana keuangan tahunan pemerintah daerah yang disetujui oleh Dewan Perwakilan Rakyat Daerah. Menurut Halim dan Kusufi (2013 : 107) Belanja modal merupakan pengeluaran anggaran untuk perolehan aset tetap dan aset lainnya yang membermanfaat lebih dari satu periode.

\subsection{Kinerja Keuangan}

Kinerja keuangan adalah suatu ukuran kinerja yang menggunakan indikator keuangan. Analisis kinerja keuangan pada dasarnya dilakukan untuk menilai kinerja dimasa lalu dengan melakukan berbagai analisis sehingga diperoleh posisi keuangan yang mewakili realitas entitas dan potensipotensi kinerja yang akan berlanjut (Nugroho dan Rohman, 2012:3). Adapun parameter yang digunakan dalam rasio keuangan pemerintah harus disesuaikan dengan komponen dalam anggaran pendapatan dan belanja daerah, yaitu:
1. Rasio Kemandirian adalah:

$\frac{\text { Pendapatan Asli Daerah }}{\text { Jumlah Belanja Rutin Non Belanja Pegawai }}$

2. Kemampuan Mobilisasi Daerah adalah:

$\frac{\text { Pajak Daerah }}{\text { Pendapatan Asli Daerah }}$

3. Efisiensi Pengeluaran Anggaran adalah:

$\frac{\text { Total Sisa Anggaran }}{\text { Total Belanja Daerah }}$

4. Sisa Pengeluaran Anggaran adalah:

$\frac{\text { Total Pengeluaran Lainnya }}{\text { Total Belanja Daerah }}$

\section{METODOLOGI PENELITIAN}

Jenis penelitian yang digunakan yaitu studi kasus jenis kuantitatif. Populasi dalam penelitian ini adalah 38 kabupaten/ Kota di Jawa Timur dengan sampel sebanyak 38 pengamatan yang diperoleh dari 38 Kabupaten/ Kota dikalikan dengan periode penelitian selama 1 tahun. Penarikan sampel tersebut menggunakan metode Purposive sampling. Penelitian ini menggunakan variabel Pendapatan Asli Daerah (PAD), Pertumbuhan Kinerja Keuangan sebagai variabel independen serta Belanja Modal sebagai variabel dependent yang bersumber dari data Laporan Realisasi APBD pada tahun 2013. Data dikumpulkan dengan metode 
dokumentasi yang bersumber dari Badan Pusat Statistik Provinsi Jawa Timur dan Situs Resmi Dirjen Perimbangan Keuangan Daerah. Metode (tehnik) yang digunakan untuk menganalisis hipotesis dalam penelitian ini adalah metode regresi linier berganda dan analisis jalur (path analiysis) dengan bantuan program SPSS versi 20. Adapun bentuk Persamaanya adalah:

1. Regresi Linier Berganda

$$
\begin{aligned}
& \mathrm{PAD}=\alpha+\beta_{1} \mathrm{BM}+\mathrm{e} 1 \\
& \mathrm{PKK}=\alpha+\beta_{2} \mathrm{PAD}+\mathrm{e} 2
\end{aligned}
$$

Dimana:

$$
\begin{array}{ll}
\mathrm{BM} & =\text { Belanja Modal } \\
\alpha & =\text { Kostanta } \\
\beta_{1}, \beta_{2}= & \text { Koefisien Regresi } \\
\text { PAD }= & \text { Pendapatan Asli Daerah } \\
\text { PKK }= & \text { Pertumbuhan Kinerja } \\
& \text { Keuangan } \\
\mathrm{e} & =\text { Error }
\end{array}
$$

2. Analisis Jalur (Path Analiysis)

$\mathrm{PAD}=\mathrm{p} 1 \mathrm{BM}+\mathrm{e} 1$

$\mathrm{PKK}=\mathrm{p} 1 \mathrm{BM}+\mathrm{p} 2 \mathrm{PAD}+\mathrm{e} 2$

Dimana:

$$
\begin{aligned}
\mathrm{BM} & =\text { Belanja Modal } \\
\mathrm{PAD} & =\text { Pendapatan Asli } \\
& \text { Daerah }
\end{aligned}
$$

PKK = Pertumbuhan Kinerja

$$
\begin{array}{ll} 
& \text { Keuangan } \\
\mathrm{p}_{1}, \mathrm{p}_{2}, \mathrm{p}_{3} & =\text { Koefisien Jalur } \\
\mathrm{e}_{1}, \mathrm{e}_{2} & =\text { Variabel Residu }
\end{array}
$$

\section{HASIL PENELITIAN DAN PEMBAHASAN}

\subsection{Analisis Deskriptif}

Berdasarkan Tabel 1, dapat diketahui bahwa nilai Pendapatan Asli Daerah (PAD) maksimum 53,32 dengan rata-rata 12,0711. Sedangkan Belanja Modal (BM) maksimum sebesar 28,25 dengan rata-rata

17,2924 .

Tabel 1. Statistik Deskriptif

\begin{tabular}{|l|c|c|c|c|c|}
\hline & $\mathbf{N}$ & Minimum & Maksimum & Mean & Std. Deviation \\
\hline PAD & 38 & 5.93 & 53.32 & 12.0711 & 8.83279 \\
\hline kinerja_RK & 38 & -15.19 & 92.96 & 26.1163 & 16.90849 \\
\hline kinerja_KMD & 38 & 10.89 & 77.18 & 32.6366 & 20.11615 \\
\hline kinerja_EPA & 38 & -3.53 & 12.68 & 4.1079 & 3.97732 \\
\hline kinerja_SPA & 38 & 0.00 & 0.68 & 0.0553 & 0.11788 \\
\hline BM & 38 & 7.94 & 28.25 & 17.2924 & 4.64442 \\
\hline
\end{tabular}


4.2 Analisis Regresi Belanja Modal terhadap Pendapatan Asli Daerah

Berikut ini adalah hasil uji $\mathrm{F}$ dan uji $\mathrm{t}$ analisis regresi belanja modal terhadap PAD

1. Uji Statistik F menunjukkan perhitungan uji $\mathrm{F}_{\text {hitung }}$ sebesar 6,198 > $F_{\text {tabel }}$ 3,27 dengan nilai signifikansi 0,018 . Oleh karena nilai signifikansi $0,018<0,05$ yang berarti secara simultan variabel independen Belanja Modal berpengaruh secara signifikan terhadap variabel dependen PAD.

2. Uji Statistik $\mathrm{t}$

$$
\mathrm{PAD}=-0,532+0,729 \mathrm{BM}+\mathrm{e} 1
$$

Dari persamaan tersebut dapat diketahui bahwa nilai konstanta sebesar -0,532 memiliki arti apabila Belanja Modal nilainya nol (0) maka PAD turun sebesar $0,532 \%$. Nilai koefisien regresi untuk Belanja Modal sebesar 0,729 memiliki arti apabila Belanja Modal naik 1\% maka PAD naik sebesar 0,729\% dengan asumsi variabel lainnya konstan. Hipotesis $1\left(\mathrm{H}_{1}\right)$ menyatakan bahwa Belanja Modal berpengaruh terhadap Pendapatan Asli Daerah dari tabel 5.8, nilai Unstandardized Beta untuk pengaruh Belanja Modal terhadap
PAD sebesar 0,532 dengan $t_{\text {hitung }} 2,489$ $>t_{\text {tabel }} 2,02809$, dan signifikasi $0,018<$ 0,05 menunjukkan bahwa variabel Belanja Modal berpengaruh terhadap PAD, yang berarti $\mathrm{H}_{1}$ diterima.

\subsection{Analisis Regresi Pendapatan Asli Daerah terhadap Pertumbuhan Kinerja Keuangan}

Hasil uji $\mathrm{F}$ dan uji t analisis regresi PAD terhadap pertumbuhan kinerja keuangan adalah sebagai berikut:

1. Uji Statistik F menunjukkan perhitungan uji $F_{\text {hitung sebesar }}$ $119,558>F_{\text {tabel }} 3,27$ dengan nilai signifikansi 0,000 . Oleh karena nilai signifikansi $0,000<0,05$ yang berarti secara simultan variabel independen PADberpengaruh signifikan terhadap variabel dependen Pertumbuhan Kinerja Keuangan (Rasio Kemandirian).

2. Uji Statistik $\mathrm{t}$

$$
\begin{aligned}
& \text { PKK }=5,858+1,678 \mathrm{PAD}+\mathrm{e} 2 \\
& \text { Dari persamaan tersebut dapat }
\end{aligned}
$$
diketahui bahwa nilai konstanta sebesar 5,858 memiliki arti apabila PAD nilainya nol (0) maka Pertumbuhan Kinerja Keuangan (Rasio Kemandirian) sebesar 585,8\%. Nilai koefisien regresi untuk PAD sebesar 1,678 memiliki arti 
apabila PAD naik $1 \%$ maka Pertumbuhan Kinerja Keuangan (Rasio Kemandirian) naik sebesar 1,678\% dengan asumsi variabel lainnya konstan. Hipotesis $2 \quad\left(\mathrm{H}_{2}\right)$ Hipotesis 2 menyatakan bahwa PAD berpengaruh terhadap Pertumbuhan Kinerja Keuangan (Rasio Kemandirian). Dari tabel 5.14 nilai Unstandardized Beta untuk pengaruh PAD terhadap RK sebesar 1,678 dengan $t_{\text {hitung }} 10,934>t_{\text {tabel }}$ 2,02809, dan signifikasi $0,000<0,05$ menunjukkan bahwa variabel PAD berpengaruh terhadap Pertumbuhan Kinerja Keuangan (RK), yang berarti $\mathrm{H}_{2}$ diterima.

\subsection{Analisis Regresi Pendapatan Asli Daerah terhadap Kemampuan Mobilisasi Daerah}

Uji $F$ dan uji $t$ dari analisis regresi antara PAD terhadap kemampuan mobilisasi daerah adalah sebagai berikut:

1. Uji Statistik F menunjukkan perhitungan uji $F_{\text {hitung }}$ sebesar 31,309> $F_{\text {tabel }} 3,27$ dengan nilai signifikansi 0,004 . Oleh karena nilai signifikansi $0,000<0,05$ yang berarti secara simultan variabel independen PAD berpengaruh signifikan terhadap variabel dependen
Pertumbuhan Kinerja Keuangan

(Kemampuan Mobilisasi Daerah).

2. Uji Statistik $\mathrm{t}$

$\mathrm{KMD}=13,887+1,553 \mathrm{PAD}+\mathrm{e} 2$

Dari persamaan tersebut dapat diketahui bahwa nilai konstanta sebesar 13,887 memiliki arti apabila PAD nilainya nol (0) maka Pertumbuhan Kinerja Keuangan (Rasio Kemampuan Mobilisasi Daerah) sebesar 1388,7\%. Nilai koefisien regresi untuk PAD sebesar 1,553 memiliki arti apabila PAD naik $1 \%$ maka Pertumbuhan Kinerja Keuangan (Rasio Kemampuan Mobilisasi Daerah) naik sebesar 1,553\% dengan asumsi variabel lainnya konstan. $\begin{array}{lllll}\text { Hipotesis } 2 & \left(\mathrm{H}_{2}\right) & \text { Hipotesis } & 2\end{array}$ menyatakan bahwa PAD berpengaruh terhadap Pertumbuhan Kinerja Keuangan (Rasio Kemampuan Mobilisasi Daerah). Dari tabel 5.20 nilai Unstandardized Beta untuk pengaruh PAD terhadap KMD sebesar 1,553 dengan $t_{\text {hitung }} 5,595>t_{\text {tabel }} 2,02809$, dan signifikasi $0,000<0,05$ menunjukkan bahwa variabel PAD berpengaruh terhadap Pertumbuhan Kinerja Keuangan (KMD), yang berarti $\mathrm{H}_{2}$ diterima. 
4.5 Analisis Regresi Pendapatan Asli Daerah terhadap Efisiensi

\section{Pengeluaran Anggaran}

Hasil uji simultan F dan uji secara parsial $\mathrm{t}$ dari analisis regresi PAD terhadap efisiensi pengeluaran anggaran adalah sebagai berikut:

1. Uji Statistik F menunjukkan perhitungan uji $F_{\text {hitung }}$ sebesar $0,008<\mathrm{F}_{\text {tabel }} \quad 3,27$ dengan nilai signifikansi 0,929. Oleh karena nilai signifikansi 0,929>0,05 yang berarti secara simultan variabel independen PAD tidak berpengaruh signifikan terhadap variabel dependen Pertumbuhan Kinerja Keuangan (Efisiensi Pengeluaran Anggaran).

\section{Uji Statistik t}

$\mathrm{EPA}=4.027+0,007 \mathrm{PAD}+\mathrm{e} 2$

Dari persamaan tersebut dapat diketahui bahwa nilai konstanta sebesar 4,027 memiliki arti apabila PAD nilainya nol (0) maka Pertumbuhan Kinerja Keuangan (Rasio Efisiensi Penggeluaran Anggaran) sebesar 402,7\%. Nilai koefisien regresi untuk PAD sebesar 0,007 memiliki arti apabila PAD naik $1 \%$ maka Pertumbuhan Kinerja Keuangan (Rasio Efisiensi Penggeluaran Anggaran) naik sebesar $00,7 \%$ dengan asumsi variabel lainnya konstan. Hipotesis $2 \quad\left(\mathrm{H}_{2}\right)$ Hipotesis 2 menyatakan bahwa PAD berpengaruh terhadap Pertumbuhan Kinerja Keuangan (Rasio Efisiensi Pengeluaran Anggaran). Dari tabel 5.26 Unstandardized Beta untuk pengaruh PAD terhadap EPA sebesar 0,007 dengan $t_{\text {hitung }} 0,090<t_{\text {tabel }} 2,028$ dan signifikasi $0,929>0,05$ menunjukkan bahwa variabel PAD tidak berpengaruh terhadap Pertumbuhan Kinerja Keuangan (EPA), yang berarti $\mathrm{H}_{2}$ ditolak.

\subsection{Analisis Regresi Pendapatan Asli Daerah terhadap Sisa Pengeluaran Anggaran}

Berikut ini adalah hasil uji simultan $\mathrm{F}$ dan uji parsial t pada analisis regresi PAD terhadap sisa pengeluaran anggaran:

1. Uji Statistik F menunjukkan perhitungan uji $F_{\text {hitung sebesar }}$ $0,989<F_{\text {tabel }} 3,27$ dengan nilai signifikansi 0,327. Oleh karena nilai signifikansi $0,327>0,05$ yang berarti secara simultan variabel independen PAD tidak berpengaruh secara signifikan terhadap variabel dependen Pertumbuhan Kinerja Keuangan (Sisa Pengeluaran Anggaran). 
2. Uji Statistik t

$\mathrm{SPA}=0,082+-0,002 \mathrm{PAD}+\mathrm{e} 2$

Dari persamaan tersebut dapat diketahui bahwa nilai konstanta sebesar 0,082 memiliki arti apabila PAD nilainya nol (0) maka Pertumbuhan Kinerja Keuangan (Rasio Sisa Pengeluaran Anggaran) sebesar 08,2\%. Nilai koefisien regresi untuk PAD sebesar -0,002 memiliki arti apabila PAD naik $1 \%$ maka Pertumbuhan Kinerja Keuangan (Rasio Sisa Pengeluaran Anggaran) turun sebesar $0,002 \%$ dengan asumsi variabel lainnya konstan. Hipotesis $2\left(\mathrm{H}_{2}\right)$ Hipotesis 2 menyatakan bahwa PAD berpengaruh terhadap Pertumbuhan Kinerja Keuangan (Rasio Sisa Pengeluaran Anggaran). Dari tabel 5.44 Unstandardized Beta untuk pengaruh PAD terhadap SPA sebesar $-0,002$ dengan $t_{\text {hitung }}-0,995<t_{\text {tabel }} 2,02809$, dan signifikasi 0,327> 0,05 menunjukkan bahwa variabel PAD tidak berpengaruh secara negatif dan tidak signifikan terhadap Pertumbuhan Kinerja Keuangan (SPA), yang berarti $\mathrm{H}_{2}$ ditolak.

\subsection{Analisis Jalur (Path Analysis)}

Persamaan 1 :

$\mathrm{PAD}=\mathrm{p}_{1} \mathrm{BM}+\mathrm{e} 1$
Hasil output SPSS memberikan nilai standardized beta Belanja Modal pada persamaan 1 sebesar 0,383 dan signifikan pada 0,018 yang berarti Belanja Modal mempengaruhi Pendapatan Asli Daerah. Nilai koefisien standardized beta 0,383 merupakan nilai part atau jalur p2.

Persamaan 2 :

$\mathrm{PKK}=\mathrm{p}_{1} \mathrm{BM}+\mathrm{p}_{2} \mathrm{PAD}+\mathrm{e} 2$

Pada output SPSS persamaan regresi 2 nilai setandardized beta untuk Belanja Modal -0,118 dan Pendapatan Asli Daerah 0,922 semuanya signifikan. Nilai standardized beta Belanja Modal 0,118 merupakan nilai jalur path $\mathrm{p} 1$ dan nilai standardized beta Pendapatan Asli Daerah 0,922 merupakan nilai jalur path p3. Besarnya e1 $=\sqrt{1-0,123}=0,936$ dan besarnya nilai e2 $=\sqrt{1-0,780}=$ 0,608. Hasil analisis jalur menunjukkan Belanja Modal dapat berpengaruh langsung ke Pertumbuhan Kinerja Keuangan dan dapat juga berpengaruh tidak langsung yaitu dari Belanja Modal ke Pendapatan Asli Daerah (sebagai intervening) lalu ke Pertumbuhan Kinerja Keuangan. Besarnya berpengaruh langsung adalah $-0,118$ sedangkan besarnya pengaruh tidak langsung harus dihitung dengan 
mengalikan koefisien tidak langsungnya yaitu $(0,383) \times(0,922)=0,353$. Atau total pengaruh belanja modal ke pertumbuhan kinerja keuangan $=-0,118$ $+(0,383 \times 0,922)=0,235$.

Pada output SPSS persamaan regresi 2 nilai setandardized beta untuk Belanja Modal 0,224 dan Pendapatan Asli Daerah 0,596 semuanya signifikan. Nilai standardized beta Belanja Modal 0,224 merupakan nilai jalur path $\mathrm{p} 1$ dan nilai standardized beta Pendapatan Asli Daerah 0,596 merupakan nilai jalur path p3. Besarnya e1 $=\sqrt{1-0,123}=0,936$ dan besarnya nilai e2 $=\sqrt{1-0,508}=$ 0,713 . Hasil analisis jalur menunjukkan Belanja Modal dapat berpengaruh langsung ke Pertumbuhan Kinerja Keuangan dan dapat juga berpengaruh tidak langsung yaitu dari Belanja Modal ke Pendapatan Asli Daerah (sebagai intervening) lalu ke Pertumbuhan Kinerja Keuangan. Besarnya berpengaruh langsung adalah 0,224 sedangkan besarnya pengaruh tidak langsung harus dihitung dengan mengalikan koefisien tidak langsungnya yaitu $(0,383) \times(0,596)=0,228$. Atau total pengaruh belanja modal ke pertumbuhan kinerja keuangan $=0,224$ $+(0,383 \times 0,596)=0,452$.
Pada output SPSS persamaan regresi 2 nilai setandardized beta untuk Belanja Modal -0,519 dan Pendapatan Asli Daerah 0,214 semuanya signifikan. Nilai standardized beta Belanja Modal 0,519 merupakan nilai jalur path p1 dan nilai standardized beta Pendapatan Asli Daerah 0,214 merupakan nilai jalur path p3. Besarnya $\mathrm{e} 1=\sqrt{1-0,123}=0,936$ dan besarnya nilai e2 $=\sqrt{1-0,230}=$ 0,770. Hasil analisis jalur menunjukkan Belanja Modal dapat berpengaruh langsung ke Pertumbuhan Kinerja Keuangan dan dapat juga berpengaruh tidak langsung yaitu dari Belanja Modal ke Pendapatan Asli Daerah (sebagai intervening) lalu ke Pertumbuhan Kinerja Keuangan. Besarnya berpengaruh langsung adalah -0,519 sedangkan besarnya pengaruh tidak langsung harus dihitung dengan mengalikan koefisien tidak langsungnya yaitu $(0,383) \times(0,214)=0,082$. Atau total pengaruh belanja modal ke pertumbuhan kinerja keuangan $=-0,519$ $+(0,383 \times 0,214)=-0,437$.

Pada output SPSS persamaan regresi 2 nilai setandardized beta untuk Belanja Modal -0,120 dan Pendapatan Asli Daerah $\quad-0,118$ semuanya signifikan. Nilai standardized beta Belanja Modal -0,120 merupakan nilai 
jalur path p1 dan nilai standardized beta Pendapatan Asli Daerah -0,118 merupakan nilai jalur path p3. Besarnya $\mathrm{e} 1=\sqrt{1-0,123}=0,936$ dan besarnya nilai e2 $=\sqrt{1-0,039}=0,961$. Hasil analisis jalur menunjukkan Belanja Modal dapat berpengaruh langsung ke Pertumbuhan Kinerja Keuangan dan dapat juga berpengaruh tidak langsung yaitu dari Belanja Modal ke Pendapatan Asli Daerah (sebagai intervening) lalu ke Pertumbuhan Kinerja Keuangan. Besarnya berpengaruh langsung adalah $-0,120$ sedangkan besarnya pengaruh tidak langsung harus dihitung dengan mengalikan koefisien tidak langsungnya yaitu $(0,383) \times(-0,118)=-0,045$. Atau total pengaruh belanja modal ke pertumbuhan kinerja keuangan $=-0,120$ $+(0,383 \times-0,118)=-0,165$.

\subsection{Analisis Pengaruh Belanja Modal terhadap Kinerja Keuangan dengan Pendapatan Asli Daerah sebagai Variabel Intervening}

Dengan meningkatnya belanja modal berarti pemerintah telah meningkatkan infranstruktur yang ada sehingga akan meningkatkan produktifitas masyarakat dan menarik investor sehingga nantinya akan berdampak pada peningkatan PAD.
PAD dapat dijadikan tolak ukur mengetahui tingkat kemandirian suatu daerah karena mencerminkan bagaimana suatu daerah mendanai kegiatannya melalui komponen pendapatan murni yang dihasilkan daerah tersebut.

Pengukuran kinerja merupakan suatu proses sistematis untuk menilai program yang direncanakan sesuai dengan target. Di lihat dari hasil penelitian menunjukkan bahwa rasio kemandirian dan kemampuan mobilisasi daerah berpengaruh positif dan signifikan karena jika PAD meningkat berarti menggambarkan kemampuan atau tingkat kesejahteraan masyarakat dalam membayar pajak dan pungutan lainnya sehingga mengurangi ketergantungan terhadap pemerintah pusat serta meningkatkan kemampuan daerah dalam membiayai belanjany sendiri.

Sedangkan untuk efisiensi pengeluaran anggaran dan sisa pengeluaran anggaran berpengaruh negatif dan tidak signifikan. Ini membuktikan bahwa keefisienan suatu pengeluaran tidak sesuai dengan realisasi pendapatan yang di terima karena biaya yang dikeluarkan lebih besar. Hal ini memunculkan dilema 
tentang moral hazard terhdap penggunaan PAD.

\section{PENUTUP}

\subsection{Simpulan}

Belanja Modal berpengaruh positif dan signifikan terhadap Pendapatan Asli Daerah. Karena dengan meningkatnya belanja modal berarti pemerintah telah meningkatkan infranstruktur yang ada sehingga akan meningkatkan produktifitas masyarakat dan menarik investor yang nantinya akan berdampak pada peningkatan PAD.

Pendapatan Asli Daerah berpengaruh secara positif dan signifikan terhadap pertumbuhan kinerja keuangan rasio kemandirian dan kemampuan mobilisasi daerah. menunjukkan bahwa dengan meningkatnya PAD suatu daerah menggambarkan kemampuan atau tigkat kesejahteraan masyarakat dalam membayar pajak dan pungutan lainnya. Peningkatan PAD akan meningkatkan kemandirian suatu daerah agar tidak bergantung pada pemerintah pusat.

Pendapatan Asli Daerah berpengaruh secara negatif dan tidak signifikan terhadap pertumbuhan kinerja keuangan efisiensi penggeluaran anggaran dan sisa pengeluaran anggaran. Hal ini membuktikan bahwa keefisiensian suatu pengeluaran tidak sesuai atau tidak sebanding dengan realisasi pendapatan yang diterima karena biaya yang dikeluarkan untuk merealisasikan target penerimaan pendapatan lebih besar dari pada realisasi pendapatan yang diterima.

\subsection{Saran}

Bagi pemerintah diharapkan dapat mengembangkan sumber-sumber pendapatan daerah sehingga dapat meningkatkan PAD, memperhatikan alokasi belanja yang akan dikeluarkan, meningkatkan kinerja dalam pelayanan publik dan tidak melakukan penyelewengan anggaran. Sedangkan bagi peneliti selanjutnya agar menggunakan data laporan keuangan paling tidak lima tahun terakhir sehingga hasilnya dapat digeneralisir, menambahkan indikator pengukuran kinerja, dan memperluas objek penelitian.

\section{DAFTAR PUSTAKA}

Halim, Abdul, dan Muhammad Syam Kusufi. 2013. Akuntansi Keuangan Daerah. Jakarta : Salemba 4. 
Nugroho, Fajar dan Abdul Rohman.

2012. Pengaruh Belanja Modal

Terhadap Pertumbuhan Kinerja

Keuangan Daerah Dengan

Pendapatan Asli Daerah Sebagai

Variabel Intervening (Studi

Kasus di Provinsi Jawa Tengah).

Diponegoro Jaurnal of

Accounting. 1 (2): 1-14.

Republik Indonesia. 2010. Peraturan

Pemerintah Nomor 71 tahun

2010 tentang Standar Akuntansi

Pemerintahan.

Wenny, Cerrya Dhia. 2012. Analisis Pengaruh Pendapatan Asli Daerah (PAD) Terhadap Kinerja Keuangan pada Pemerintah Kabupaten dan Kota di Provinsi Sumatera Selatan. Jurnal Ilmiah STIE MDP. 2 (1): 39-

51. 